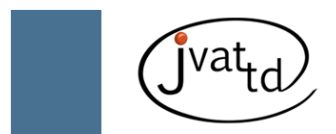

\title{
Tumor cytotoxicity of leucurolysin-B, a P-III snake venom metalloproteinase from Bothrops leucurus
}

\author{
Gabriel LM (1), Sanchez EF (2), Silva SG (2), Santos RG $(1,3)$
}

(1) Center for Development of Nuclear Technology/Brazilian Nuclear Energy Commission (CDTN/ CNEN), Belo Horizonte, Minas Gerais State, Brazil; (2) Ezequiel Dias Foundation (FUNED), Belo Horizonte, Minas Gerais State, Brazil; (3) Brazil National Institute of Science and Technology of Molecular Medicine (INCT-MM), Belo Horizonte, Minas Gerais State, Brazil.

\begin{abstract}
Although it has been demonstrated that venoms and toxins from some snakes are able to influence the growth of tumor cells, few antitumoral compounds from Bothrops leucurus venom have been characterized. Leucurolysin-B (leuc-B) is a metalloproteinase class P-III isolated from B. leucurus which possesses an ECD-disintegrin domain. Both ECD-disentegrin and RGD-disintegrin are able to bind to cell surface integrins and inhibit their adherence to their natural ligands. In the present study, the potential efficacy and the cytotoxic effects of leuc-B on glioblastoma, breast cancer and melanoma cell lines were analyzed. The effect of leuc-B on cancer cell survival was evaluated and its $50 \%$ inhibitory concentration $\left(\mathrm{IC}_{50}\right)$ was determined. Morphological alterations were monitored by contrast phase and fluorescent microscopy. The results demonstrated that leuc-B has potent cytotoxic effect in a micromolar range against all evaluated cancer cell lines. Morphologically, dying cells showed fragmentation, condensation of their contents concomitant with shrinkage and appearance of vacuoles. This study reports for the first time the cytotoxic effect of leuc-B from B. leucurus snake venom on tumor cells.
\end{abstract}

Key words: snake venom, leucurolysin-B, ECD-disintegrin, tumor, in vitro study.

\section{INTRODUCTION}

Tumor cells are characterized by uncontrolled growth, invasion into surrounding tissues, and metastatic spread to distant sites (1). According to the report of the International Agency for Research on Cancer, the increase of this disease implies the death of 17 million people a year by 2030 (2).

Membrane receptors overexpressed in tumor cells are promising target candidates for development of diagnostic and therapeutic tools. Several snake venom toxins have been referenced as inhibiting cancer cell adhesion, migration, tumor growth and metastasis in experimental mice models (3).

The extracellular matrix (ECM) regulates cell behavior and orchestrates cellular functions such as growth, differentiation, death, shape, motility and cell adhesion. This control is done through a signal transduction from ECM to the cells, which is largely mediated by integrin receptors that play a key role in organizing the components of the cytoskeleton. Consequently, an important change in focal adhesion induces a variety of cellular responses, which can lead to programmed cell death, known as apoptosis. A particular type of apoptosis denominated "anoikis" can be evoked by molecules that degrade the ECM, such as matrix metalloproteinases (MMP). Metalloproteinases isolated from snake venoms (SVMP) can also degrade ECM proteins and interfere in various interactive processes between cells and the extracellular matrix, through the inhibition of integrin receptors (4).

ECM-controlled signaling ensures that cells divide and differentiate only as needed by the organism. Thus, tumor cells must remodel 
the matrix to facilitate communication and escape control by the microenvironment (5). Interference in cell adhesion mediated by integrin implies the pathogenesis of many diseases such as atherosclerosis, cancer and a variety of inflammatory processes. These conditions make integrins attractive targets for developing new therapeutic agents against cancer $(6,7)$.

Integrins work as receptors for several types of cell matrix proteins including collagen, fibronectin, lamin, vitronectin, and fibrinogen (8). These adhesive proteins possess specific amino acid sequences containing aspartic acid, which are important for recognizing and binding to integrins. The most frequent and most studied of these sequences is arginine-glycine-aspartic acid (Arg-Gly-Asp or RGD) (9). RGD and ECD sequences can also be found in some snake venom components where they are denominated disintegrins. Disintegrins are proteins that inhibit integrin-mediated cell-cell and cell-matrix interactions (10). For many years it has been known that administration of soluble synthetic peptides containing the RGD sequence inhibits the formation of metastasis (11). However, the inhibition of cell adhesion promoted by disintegrins containing the RGD sequence is more powerful than the effect of synthetic RGD peptides (10). It has been reported that 1.5 and $3 \mathrm{mg}$ of the synthetic peptide GRGDS, when coinjected with $\mathrm{B} 16 \mathrm{~F} 1 \mathrm{O}$ cells (mouse melanoma), inhibit lung colonization in C57BL/ 6 mice by 50 and $90 \%$, respectively. In contrast, contortrostatin (snake venom disintegrin) at only 20 and 100 $\mu \mathrm{g}$ inhibits lung colonization of $5 \times 10^{5}$ cells by approximately 50 and $75 \%$ in $\mathrm{C} 57 \mathrm{BL} / 6$ mice, respectively (10).

Thus, the study of snake venom disintegrins is extremely important in the search for a new anticancer therapy tool. Both ECD-disintegrin and RGD-disintegrin are able to bind to cell surface integrins and promote inhibition of cell adhesion (12).

Leuc-B exhibits the characteristic motif of metalloproteinases, HEXXHXXGXXH and a methionine-containing turn of similar conformation ("Metturn"), which form a hydrophobic basis for the zinc ions and the three histidine residues involved as ligands. Leuc-B is characterized as a P-III metalloproteinase and possesses a disintegrin-like (ECD sequence instead of the typical RGD motif) and a cysteine- rich C-terminal domain. This proteinase presents an apparent molecular mass of $55 \mathrm{kDa}$. The enzyme only cleaves the Ala14-Leu15 peptide bond of the oxidized insulin B-chain and preferentially hydrolyzes the Aa-chain of fibrinogen and the a-chain of fibrin. Its proteolytic activity was completely inhibited by metal chelating agents but not by other typical proteinase inhibitors. In addition, its enzymatic activity was stimulated by the divalent cations $\mathrm{Ca}^{2+}$ and $\mathrm{Mg}^{2+}$ but inhibited by $\mathrm{Zn}^{2+}$ and $\mathrm{Cu}^{2+}$. The catalytic action of leuc-B on extracellular matrix proteins could readily lead to loss of capillary integrity resulting in hemorrhage at those sites (MHD = $30 \mathrm{ng}$ in rabbit), with alterations in platelet function (13). The goals of this study were to identify and characterize the cytotoxic effect of leuc-B on different tumor cells lines.

\section{MATERIAL AND METHODS}

\section{Reagents}

All chemicals used were of analytical grade.

\section{The Venom}

The venom of B. leucurus, obtained from several specimens from the state of Bahia, was a gift of the serpentarium Ezequiel Dias Foundation, Belo Horizonte, Minas Gerais, Brazil. The venom was lyophilized and kept at $-20^{\circ} \mathrm{C}$ until use.

\section{Purification of Leucurolysin-B}

The entire procedure of leucurolysin-B purification was conducted according to the protocol described by Sanchez et al. (13).

\section{Cell Culture}

The tumor cell lines T98 (p53 mutant malignant glioblastoma), U87 and RT2 (p53wild type malignant glioblastoma), MCF7 (mammary carcinoma), EAC (Ehrlich ascites carcinoma) and UACC (melanoma) were grown in Dulbecco's Modified Eagle's Medium (DMEM, Cultilab) culture supplemented with $10 \%$ fetal bovine serum (Cultilab, Brazil) and 50 U.mL ${ }^{-1}$ penicillin $/ 10 \mathrm{mg} / \mathrm{mL}$ streptomycin (Cultilab), cells were kept in a humidified atmosphere air/ $\mathrm{CO}_{2}(95 \% / 5 \%)$ at $37^{\circ} \mathrm{C}$. The EAC cells were provided by Dr. Geovanni Dantas Cassali, from the Department of General Pathology, Institute of Biological Sciences, Federal University of Minas Gerais. 


\section{Cytotoxicity Assay}

Cytotoxicitywas measuredby3-(4,5-Dimethyl2-thiazolyl)-2,5-diphenyl-2H-tetrazolium bromide (MTT) assay which measures the cellular metabolic viability $(14,15)$. The U87, T98, RT2, MCF7, UACC and Ehrlich tumor cells were cultured in 96-well plates and, 24 hours after incubation, they were treated with increasing concentrations of leuc-B $(0.009-3 \mu \mathrm{M})$. After 48 hours of treatment the cells were incubated with $0.5 \mathrm{mg} / \mathrm{mL}$ of MTT (Sigma Chemical Co, USA) for four hours in darkness. Subsequently, the formazan crystals were solubilized in dimethyl sulfoxide (DMSO). The absorbance was measured in a microplate reader at $570 \mathrm{~nm}$. The $\mathrm{IC}_{50}$ value (concentration of compound inducing death of $50 \%$ of cells) was determined using the program Graphpad Prism.

\section{Morphological Analysis}

Cells were plated in 96-well plates and treated with different concentrations of leuc-B ( 0.7 and $3 \mu \mathrm{M})$. Morphological changes were analyzed 48 hours after treatment by contrast-phase microscopy (Nikon, USA).

\section{DAPI Staining Assay}

DAPI (4,6- diamidine- 2'- phenindole dihydrocloride) is a fluorescent dye able to bind specifically to double strands of chromosomal DNA (16) . For analysis of chromosomal DNA changes, the U87, T98, RT2, MCF7, Ehrlich and UACC tumor cells were treated with leuc-B at the concentration of $0.7 \mu \mathrm{M}$ for 48 hours. Then, cells were washed with phosphate buffer (PBS) and fixed in methanol (70\%) for 20 minutes. Cells were incubated for 30 minutes with 0.4 $\mu \mathrm{g} / \mathrm{mL}$ of DAPI (Sigma Chemical Co., USA). DNA alterations were observed by fluorescence microscopy (Nikon,USA, 385-410 nm).

\section{Acridine Orange/Ethidium Bromide (AO/EB) Staining Assay}

Acridine orange (AO), a nucleic acid fluorescent cationic dye, has been the subject of extensive studies because of its metachromatic staining properties in relation to cell constituents (17) and can be used in conjunction with ethidium bromide to differentiate among alive, apoptotic, necrotic and autophagic cells. $\mathrm{AO}$ is taken up by both viable and dead cells, emitting green fluorescence as a result of intercalation in double-stranded DNA. Ethidium bromide is excluded from living cells. As late-phase apoptotic or necrotic cells suffer membrane disruption ethidium bromide intercalates into DNA and the cells fluoresce orange (18).

AO permeates all cells and makes the nuclei appears green. Ethidium bromide (EB) is only taken up by cells when cytoplasmic membrane integrity is lost, and stains the nucleus orange. EB also overwhelms AO. Thus, live cells present a homogeneously green nucleus; early apoptotic cells have a bright green nucleus with condensed or fragmented chromatin; late apoptotic cells display condensed and fragmented orange chromatin; cells that have died from direct necrosis show a structurally normal orange nucleus (19).

In order to detect cell death, the U87, T98, RT2, MCF7, UACC and Ehrlich tumor cells were treated with leuc-B at two different concentrations ( 0.7 and $3 \mu \mathrm{M})$ for 48 hours. Cells were incubated with solution of $\mathrm{AO} / \mathrm{EB}(1 \mu \mathrm{g} /$ $\mathrm{mL}$ ) (Sigma Chemical Co.) dissolved in DMEM culture medium. Cells were observed under a fluorescence microscope (Nikon 500, $515 \mathrm{~nm}$ ) with 400x amplification.

\section{Acridine Orange Staining}

During autophagy, acidic autophagic vacuoles, also called autophagolysosomes, are formed as a result of fusion of autophagosomes with lysosomes and are considered a characteristic feature of cells engaged in autophagy. Formation of autophagolysosomes can be detected by fluorescence microscopy following staining with the lysomotropic agent acridine orange. Staining of normal cells with acridine orange, a weak base, displays green fluorescence with cytoplasmic and nuclear components. In larger acidic compartments such as autophagolysosomes, the protonated form of acridine orange accumulates and displays red fluorescence when observed by fluorescence microscopy (20).

Cells were treated with leuc-B at two different concentrations $(0.7$ and $3 \mu \mathrm{M})$ for 48 hours. At the appropriate moment, cells were incubated with 1 $\mu \mathrm{g} / \mathrm{mL}$ acridine orange (Sigma Chemical, USA) in bovine serum (Cultilab, Brazil) for 20 minutes. The acridine orange was removed and results were acquired by fluorescent microphotography using a fluorescence microscope (Nikon 500, 515 $\mathrm{nm}$ ) with 400x amplification. The cytoplasm and nucleus of the stained cells fluoresce bright green, 
whereas the acidic autophagic vacuoles shine bright red.

\section{Statistical Analysis}

All experiments were performed in triplicate and repeated at least three times in order to verify reproducibility. Data were analyzed by ANOVA and expressed as the mean \pm standard deviation (SD) of at least three experiments. The data with $\mathrm{p}<0.05$ were considered statistically significant.

\section{RESULTS}

\section{Cytotoxicity Assay}

The results showed that leuc-B was cytotoxic in a dose-dependent manner to all tumor cell lines evaluated (Figure 1). The cytotoxic effect of leuc-B was very potent in the submicromolar range as indicated by the concentrations that inhibit cell survival by $50 \%\left(\mathrm{IC}_{50}\right.$ ) (Table 1 ). Although RT2 and Ehrlich cell lines were slightly more sensitive than U87, T98 (p53 mutant), MCF7 and UACC, these differences were not significant $(p>0.05)$ indicating that leuc-B has similar potency against wild type p53 and mutant p53 tumor cells.

\section{Morphological analysis}

Cells treated with leuc-B presented significant morphological changes such as swelling, irregularities in the plasma membrane and formation of blebs (Figure 2), indicating that leuc-B provoked cell death.

\section{DAPI staining assay}

Glioblastoma, mammary carcinoma, Ehrlich tumor and melanoma cell lines treated with leuc-B showed chromatin condensation and DNA fragmentation (Figure 3). All of these chromatin alterations occur during the apoptosis process.

\section{Acridine Orange/Ethidium Bromide (AO/EB) Staining Assay}

Figure 4 shows the results obtained from the AO/EB staining. Control cells presented homogeneously stained green nuclei, indicating viable cells. Unlike control cells, after cell treatment with $0.7 \mu \mathrm{M}$ leuc-B, nuclei of glioblastoma (Figure $4-\mathrm{B}, \mathrm{E}, \mathrm{H}$ ) and melanoma cells (Figure $4-$ Q) stained bright green indicating condensed chromatin and no plasma membrane disruption. When the cells were treated with $3 \mu \mathrm{M}$ leuc-B, nuclei were orange with focal bright orange due to EB (Figure -4 $\mathrm{C}, \mathrm{F}, \mathrm{I}, \mathrm{L}, \mathrm{O}, \mathrm{R}$ ) indicating plasma membrane disruption, condensed chromatin and apoptotic body formation. All these data on DNA analysis suggest that leuc-B has a potent cytotoxic effect on all cell lines tested.
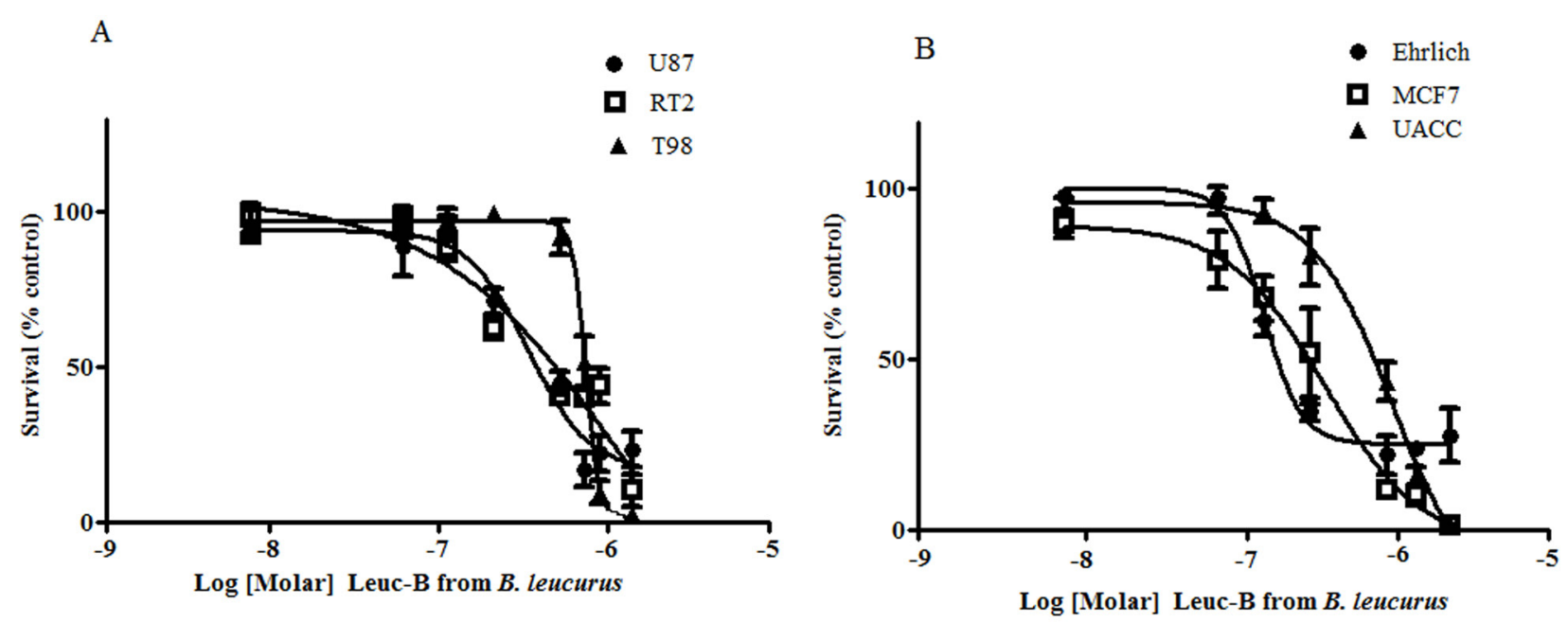

Figure 1. Cytotoxic effect of leuc-B on tumor cells: (A) U87, T98 and RT2, (B) Ehrlich, MCF7 and UACC. Cells were cultured in 96-well plates and incubated for 48 hours with different concentrations of leuc-B (0.009-3 $\mu \mathrm{M})$. Cell survival was measured by MTT. Results are presented as cell survival compared with the control group (untreated cells), $\mathrm{p}<0.05$. 
Table 1. Cytotoxic effect of treatment with leuc-B on tumor cells

\begin{tabular}{c|c}
\hline Tumor cells & IC $_{50}$ \\
\hline RT2 & $0.22 \pm 0.04 \mu \mathrm{M}$ \\
\hline T98 $^{*}$ & $0.54 \pm 0.07 \mu \mathrm{M}$ \\
\hline U87 & $0.62 \pm 0.02 \mu \mathrm{M}$ \\
\hline Ehrlich & $0.20 \pm 0.02 \mu \mathrm{M}$ \\
\hline MCF7 & $0.45 \pm 0.03 \mu \mathrm{M}$ \\
\hline UACC & $0.57 \pm 0.02 \mu \mathrm{M}$ \\
\hline
\end{tabular}

*p53 mutant, $p<0.05$

\section{Acridine orange staining}

Control cells showed predominantly green fluorescence (data not shown). Treated cells also presented green nuclei and focal bright green fluorescence suggesting no formation of autophagolysosome vacuoles during the course of leuc-B injury.

\section{DISCUSSION}

According to the World Health Organization, cancer is the second leading cause of death by disease in most countries, accounting for 7 million fatalities annually (21). For this reason, the development of alternative drugs is relevant in the attempt to improve prognosis and to increase patients' survival. Snake venoms are natural sources of bioactive substances with therapeutic potential. It has been reported that in several malignancies the overexpression of integrins is correlated with tumor progression. Thus, antagonists of integrins may provide a novel therapeutic approach for tumor treatment (22).

Integrin receptors mediate several functions including prevention of matrix detachmentinduced apoptosis (anoikis) of several adherent cell types whereas antagonists of integrins trigger an apoptotic signaling pathway (23). Recent studies show that disintegrins from SVMP can inhibit cellular adhesion of cancer cells to extracellular matrix by competing with specific integrin receptors; in addition, these proteases also inhibit metastasis (3).

SVMP, especially of the pit vipers and true vipers, are responsible for local and systemic effect due to proteolysis of the major components of the ECM. Degradation and remodeling of the ECM and BM by proteolytic enzymes are essential steps in several physiological (wound repair, tissue regeneration and embryonal development) and pathological processes including reumathoid arthritis, osteoarthritis, periodontitis, tumor development and progression. Thus, the presence of exogenous proteinases which degrade ECM can result in cell cytotoxicity (13).

Several proteins from snake venom with disintegrins and disintegrin-like domain such as salmosin from Agkistrodon halys brevicaudus, eristostatin from Eristocophis macmahoni venom and echistatin from Echis carinatus were effective in promoting cytotoxic effects on cancer cells (24-26).

More recently, Higuchi et al. (27), demonstrated that leucurogin, a recombinant disintegrinlike clone of $B$. leucurus venom, was able to inhibit collagen-induced platelet aggregation $\left(\mathrm{IC}_{50}=0.65 \mu \mathrm{M}\right)$ and growth of Ehrlich tumor implanted in mice by more than $50 \%$ after seven days of administration at $10 \mu \mathrm{g} /$ day. Leucurogin is $66 \%$ homologous to the disintegrin-like segment of leucurolysin-B venom (27).

In the present work evaluated the cytotoxic effect of leuc-B, isolated from $B$. leucurus venom on cultured tumor cells. Leuc-B evoked a dosedependent and remarkable cytotoxic effect against glioblastoma, breast cancer, Ehrlich ascites carcinonoma and melanoma cell lines with $\mathrm{IC}_{50}$ values in a micromolar range $(0.2-0.6 \mu \mathrm{M})$. Apparently, leuc-B was slightly more cytotoxic to RT2, MCF7 and Ehrlich than for U87, T98 (P53 mutant) and UACC cells, although these differences were not significant $(p<0.05)$. These data indicate that the action mechanism of leuc- $B$ may be independent of $\mathrm{p} 53$ status suggesting that this polypeptide is effective against a wide range of tumors. Nevertheless, the cytotoxic effect of leuc-B was significantly more potent (around tenfold higher) than that of cisplatin $\left(\mathrm{IC}_{50}=4\right.$ $\mu \mathrm{M})$, a chemotherapeutic agent used clinically for the treatment of tumors (28).

After leuc-B treatment, chromatin condensation was observed in all tested cell lines stained with DAPI. Although DAPI is an assay commonly used to analyze apoptosis, this method cannot rule out other types of cell death. Therefore, it is very important to analyze 

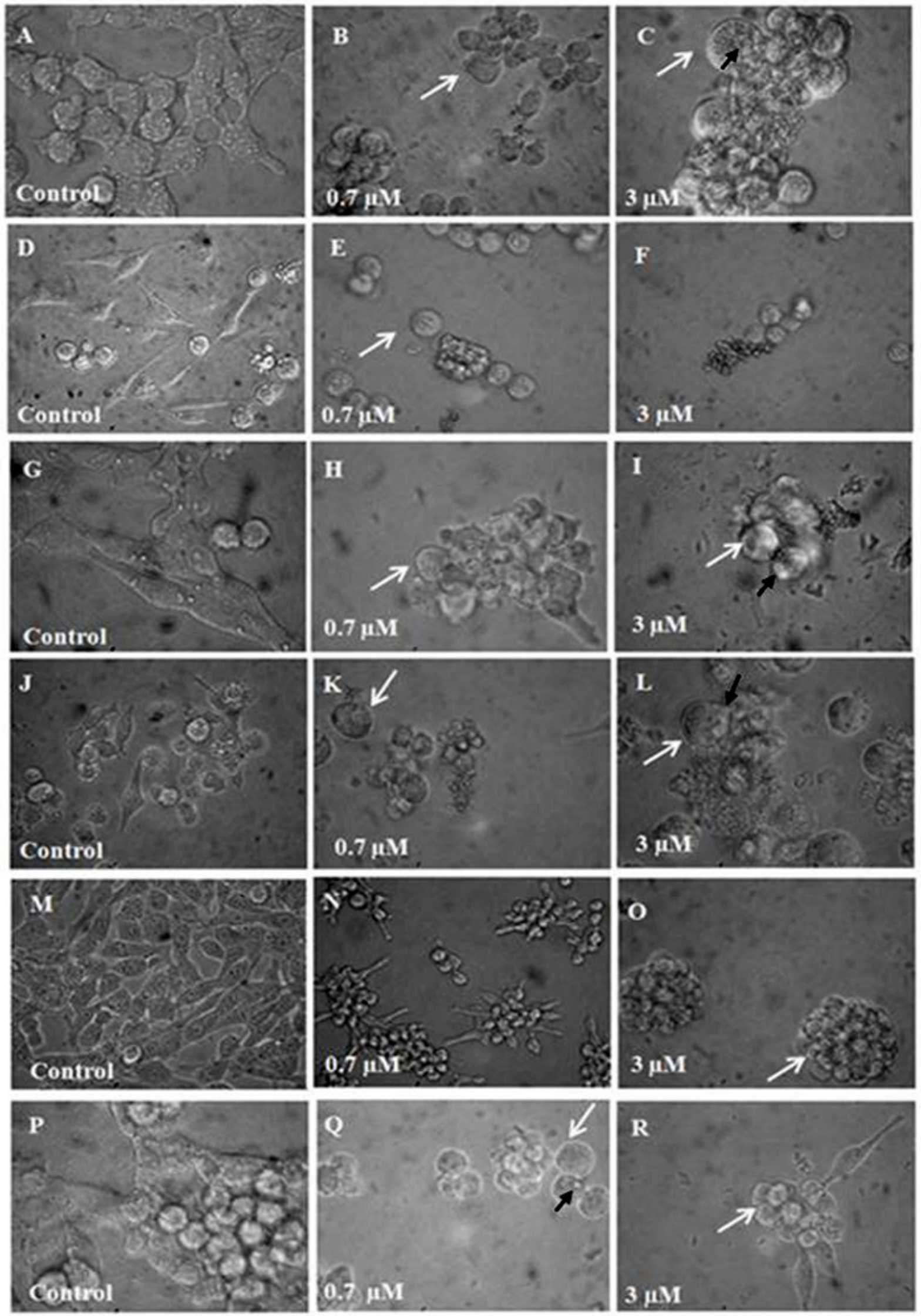

Figure 2. Morphological changes induced by leuc-B. Photomicrographs from phase-contrast microscopy of the U87 (A-C), RT2 (D-F), T98 (G-I), Ehrlich (J-L), MCF7 (M-O), UACC (P-R) tumor cells. Images were acquired by the digital camera Nikon Coolpix 4500, coupled to the MO (400x amplification). After 48 hours treated cells showed swelling (white arrows), irregularities in the plasma membrane and formation of blebs and vacuoles (black arrows). 

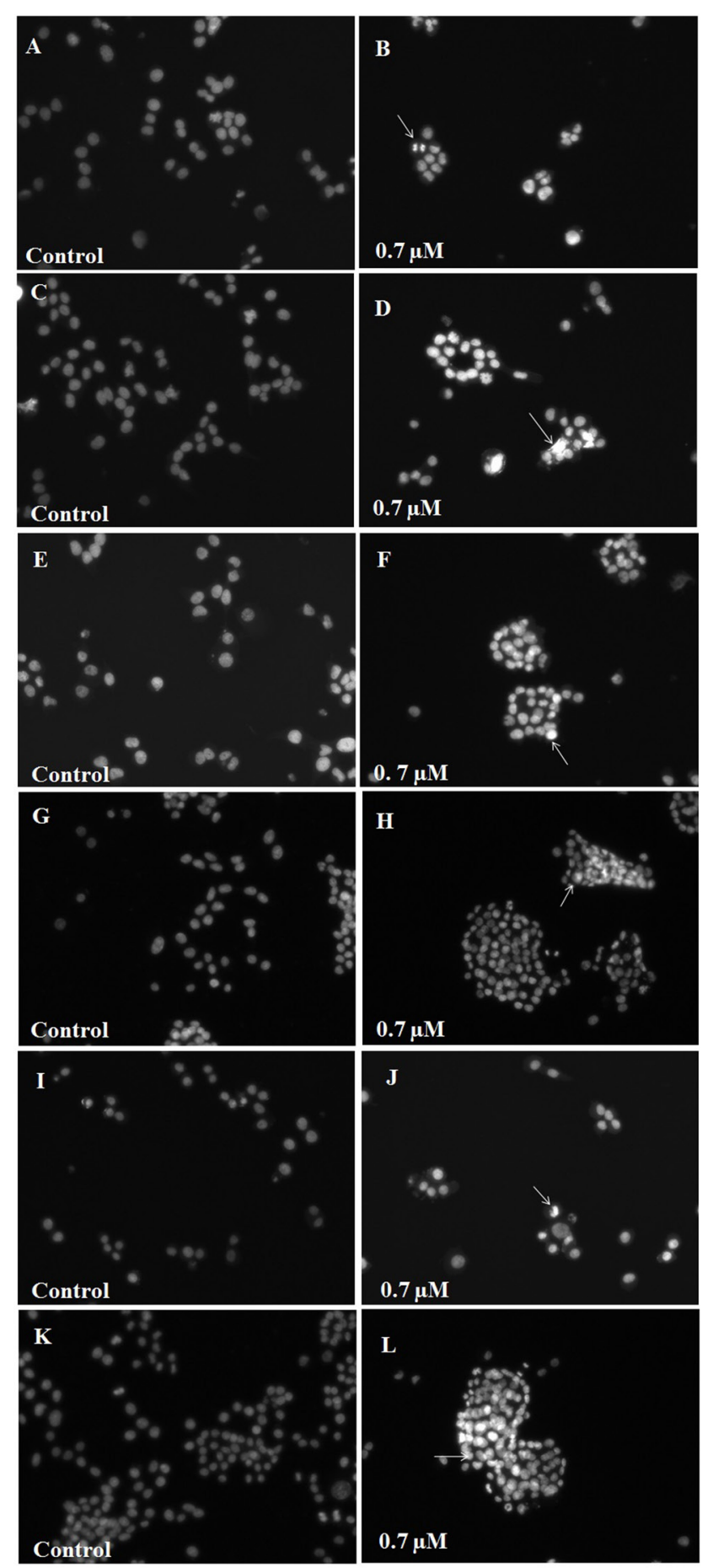

Figure 3. Analysis of nuclear condensation of U87 (A-B), RT2 (C-D), T98 (E-F), Ehrlich (G-H), MCF7 (I-J) and UACC (K-L) tumor cells: Cells were treated with $0.7 \mu \mathrm{M}$ of leuc-B. After 48 hours treated cells were stained with DAPI. Nuclear condensation (indicated by arrows) was observed in the leuc-B- treated cells. Amplification 200x. cell death using other fluorescent DNA binding dyes such as acridine orange/ethidium bromide staining (19).

$\mathrm{AO} / \mathrm{EB}$ staining produced a green fluorescence among untreated control cells due to exclusion of ethidium bromide but not of acridine orange. Viable cells showed a light green nucleus with intact structure. Leuc-B treated cells exhibited green cells with condensed chromatin and preserved membrane and cells with orange nuclei with focal bright orange due to $\mathrm{EB}$, indicating disruption of the plasmatic membrane, probably induced after the first stages of apoptotic nuclear condensation.

The results obtained with leuc-B are similar to those obtained by Bustillo et al. (29) from the venoms of $B$. diporus and $B$. alternatus, widely known to contain ECD-disintegrin (30).

All results of leuc-B are indicative of morphological changes characteristic of apoptosis including chromatin condensation, nuclear fragmentation, cellular shrinkage and bleb formation on the cell surface. Despite all data indicating leuc-B may trigger apoptosis, the role of the proteolytic activity of this SVMP P-III may not be ruled out. Actually, Sanchez et al. demonstrated that leuc-B has potent enzymatic activity and was able to hydrolyze collagen types I and IV and more efficiently their gelatins, whereas laminin from the EHS (EngelbrethHolm-Swarm) tumors was resistant to hydrolysis. In addition, the glycoproteins enactin and plasma fibronectin and vitronectin appeared to be adequate substrates (13).

In order to verify the cytotoxicity of leuc-B to non-tumor cells, a hemolytic assay was performed (data not shown) and no direct hemolysis was observed at any of the leuc-B concentrations tested $(0.009-3 \mu \mathrm{M})$. Further studies must to be done in order to shed more light on the mechanism of cell death triggered by leuc-B in tumor cells.

\section{CONCLUSIONS}

This study shows for the first time the cytotoxic effect of leuc-B from $B$. leucurus snake venom against malignant tumor cells (RT2, T98, U87, Erlich, MCF7, UACC). This cytotoxicity was very potent within the micromolar range regardless of the p53 status in all tumor cell lines evaluated in this work. 


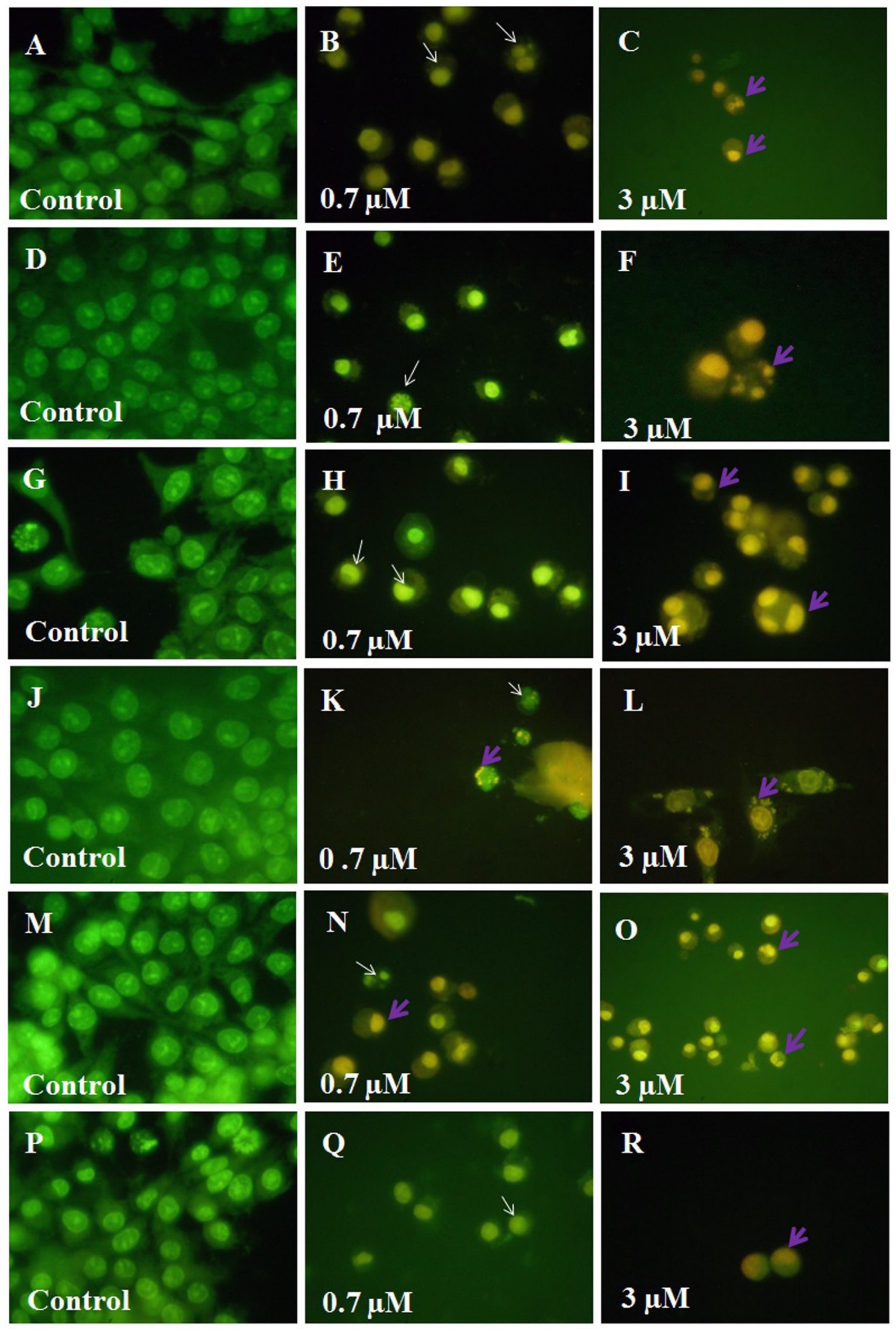

Figure 4. Analysis of cell death induced by leuc-B on U87 (A-C), RT2 (D-F), T98 (G-I), Ehrlich (J-L), MCF7 (M-O) and UACC (P-R) tumor cells. Cells were treated with $0.7 \mu \mathrm{M}$ and $3 \mu \mathrm{M}$ of leuc-B. After 48 hours, treated cells were stained with $\mathrm{AO} / \mathrm{BE}$. White arrows indicate cells in initial apoptosis and arrows indicate late apoptotic cells. Amplification of 400x. 


\section{ACKNOWLEDGEMENTS}

This work was financially supported by The Nuclear Technology Development Center / National Nuclear Energy Commission (CDTN/ CNEN), the Brazilian agencies The State of Minas Gerais Research Foundation (FAPEMIG), Coordination for the Improvement of Higher Education Personnel (CAPES) and the National Institute of Science and Technology of Molecular Medicine (INCT-MM). LMG received a fellowship from CNEN.

\section{COPYRIGHT}

(C) CEVAP 2012

\section{SUBMISSION STATUS}

Received: July 6, 2011.

Accepted: September 15, 2011.

Abstract published online: October 6, 2011.

Full paper published online: February 28, 2012.

\section{CONFLICTS OF INTEREST}

The authors declare no conflicts of interest.

\section{FINANCIAL SOURCE}

The Nuclear Technology Development Center/ National Nuclear Energy Commission (CDTN/ CNEN), The National Council for Scientific and Technological Development (CNPq), and The State of Minas Gerais Research Foundation (FAPEMIG) provided the financial grants.

\section{ETHICS COMMITTEE APPROVAL}

The present study was approved by the Ethics Committee of the Federal University of Minas Gerais (UFMG), protocol number 152/2007.

\section{CORRESPONDENCE TO}

Raquel Gouvêa dos Santos, Av. Antônio Carlos, 6627, Pampulha, Belo Horizonte, MG, 31270901, Brasil. Phone: +55313069 3177. Fax: +5531 3069 3356. Email: santosr@cdtn.br.

\section{REFERENCES}

1. Mizejewski GJ. Role of integrins in cancer: survey of expression patterns. Proc Soc Exp Biol Med. 1999;222(2):124-38.

2. The International Agency for Research on Cancer (IARC) [homepage on the Internet]. [updated 2010 Jun 15; cited 2010 Jun 15]. Available from: http:// www.iarc.fr/.

3. Corrêa Júnior MC, Maria DA, Moura-da-Silva AM, Pizzocaro KF, Ruiz IR. Inhibition of melanoma cells tumorigenicity by the snake venom toxin jararhagin. Toxicon. 2002; 40(6):739-48.

4. Tanjoni I, Weinlich R, Della-Casa MS, Clissa PB, Saldanha-Gama RF, de Freitas MS, et al. Jararhagin, a snake venom metalloproteinase, induces a specialized form of apoptosis (anoikis) selective to endothelial cells. Apoptosis. 2005;10(4):851-61.

5. Pupa SM, Ménard S, Forti S, Tagliabue E. New insights into the role of extracellular matrix during tumor onset and progression. J Cell Physiol. 2002;192(3):259-67.

6. Curley GP, Blum H, Humphries MJ. Integrins antagonists. Cell Mol Life Sci. 1999; 56(5-6):427-41.

7. Tucker GC. Inhibitors of integrins. Curr Opin Pharmacol. 2002;2(4):394-402.

8. Rádis-Baptista G. Integrins, cancer and snake toxins (mini-review). J Venom Anim Toxins incl Trop Dis. 2005;11(3):217-41.

9. Xiong JP, Stehle T, Zhang R, Joachimiak A, Frech M, Goodman SL, Arnaout MA. Crystal structure of the extracellular segment of integrin $\alpha_{\mathrm{v}} \beta_{3}$ in complex with an Arg-Gly-Asp ligant. Science. 2002;296(5565):151-5.

10. Trikha M, DeClerck YA, Markland FS. Contortrostatin, a snake venom disintegrin, inhibits $\beta 1$ integrinmediated human metastatic melanoma cell adhesion and blocks experimental metastasis. Cancer Res. 1994;54(18):4993-8.

11. Chen X, Park R, Khankaldyyan V, Gonzales-Gomez I, Tohme M, Moats RA, et al. Longitudinal microPET imaging of brain tumor growth with F-18-labeled RGD peptide. Mol Imaging Biol. 2006;8(1):9-15.

12. McLane MA, Sanchez EE, Wong A, Paquette-Straub C, Perez JC. Disintegrins. Curr Drug Targets Cardiovasc Haematol Disord. 2004;4(4):327-55.

13. Sanchez EF, Gabriel LM, Gontijo S, Gremski LH, Veiga SS, Evangelista KS, et al. Structural and functional characterization of a P-III metalloproteinase, leucurolysin-B, from B. leucurus venom. Arch Biochem Biophys. 2007;468(2):193-204.

14. Plumb JA, Miloroy R, Kaye SB. Effects of the $\mathrm{pH}$ dependence of 3-[4,5-dimetiltiazol-2-il]-2,5-difeniltetrazolium bromide-formazan absorption on chemosensitivity determined by a novel tetrazoliumbased assay. Cancer Res. 1989;49(16):4435-40.

15. Soares MA, Pujatti PB, Fortes-Dias CL, Antonelli L, Santos RG. Crotalus durissus terrificus venom as a source of antitumoral agents. J Venom Anim Toxins incl Trop Dis. 2010;16(3):480-92.

16. Kubota Y, Kubota K, Tani S. DNA binding properties of Dapi (4, 6-diamino-2-phenylindole) analogs having an imidazoline ring or a tetrahydropylindole ring: groove-binding and intercalation. Nucleic Acids Symposium. 2000;44(1):53-4.

17. Beers RF Jr. Acridine orange binding by micrococcus lysodeikticus. J Bacteriol. 1964;88(5):1249-56.

18. Ho K, Yazan LS, Ismail N, Ismail M. Apoptosis and cell cycle arrest of human colorectal cancer cell line HT29 induced by vanillin. Cancer Epidemiol. 2009;33(2): 155-60.

19. Ribble D, Goldstein NB, Norris DA, Shellman YG. A simple technique for quantifying apoptosis in 96-well plates. BMC Biotechnol. 2005;5(12):1-7 
20. Yang C, Kaushal V, Shah SV, Kaushal GP. Autophagy is associated with apoptosis in cisplatin injury to renal tubular epithelial cells. Am J Physiol Renal Physiol. 2008; 294(4):777-87.

21. World Health Organization (WHO) [homepage on the Internet]. [updated 2010 Jul 20; cited 2010 Jul 20]. Available from: http://www.who.int /cancer.

22. Kumar CC, Nie H, Rogers CP, Malkowski M, Maxwell E, Catino JJ, et al. Biochemical characterization of the binding of echistatin to integrin avb3 receptor. J Pharmacol Exp Ther. 1997;283(2):843-53.

23. Bonfoco E, Chen W, Paul R, Cheresh DA, Cooper NR. $\beta 1$ integrin antagonism on adherent, differentiated human neuroblastoma cells triggers an apoptotic signaling pathway. Neuroscience. 2000;101(4):114552.

24. Hong SY, Lee H, You WK, Chung KH, Kim DS, Song $\mathrm{K}$. The snake venom disintegrin salmosin induces apoptosis by disassembly of focal adhesion in bovine capillary endothelial cells. Biochim Biophys Res Commun. 2003;302(3):502-8.

25. Danen EHJ, Marcinkiewicz C, Cornelissen IMHA, van Kraats AA, Pachter JA, Ruiter DJ, et al. The disintegrin eristostatin interferes with integrin $\alpha 4 \beta 1$ function and with experimental metastasis of human melanoma cells. Exp Cell Res. 1998;238(1): 188-96.
26. McLane MA, Vijay-Kumar S, Marcinkiewicz C, Calvete JJ, Niewiarowsk S. Importance of the structure of the RGD-containing loop in the disintegrins echistatin and eristostatin for recognition of $\alpha_{\mathrm{IIb}} \beta_{3}$ and $\alpha_{v} \beta_{3}$ integrins. FEBS Letters. 1996;391(1-2):139-43.

27. Higuchi DA, Almeida MC, Barros CC, Sanchez EF, Pesquero PR, Lang EA, et al. Leucurogin, a new recombinant disintegrin cloned from Bothrops leucurus (white-tailed-jararaca) with potent activity upon platelet aggregation and tumor growth. Toxicon. 2011;58(1):123-9.

28. Yde CW, Issinger OG. Enhancing cisplatin sensitivity in MCF-7 human breast cancer cells by down-regulation of Bcl-2 and cyclin D1. Int J Oncol. 2006;29(6): 1397404.

29. Bustillo S, Lucero H, Leiva LC, Acosta O, Kier Joffé EB, Gorodner JO. Cytotoxicity and morphological analysis of cell death induced by Bothrops venoms from the northeast of Argentina. J Venom Anim Toxins incl Trop Dis. 2009;15(1):28-42.

30. Sant'Ana EM, Gouvêa CM, Durigan JL, Cominetti MR, Pimentel ER, Selistre-de- Araújo HS. Rat skin wound healing induced by alternagin- $\mathrm{C}$, a disintegrin-like, Cys-rich protein from Bothrops alternatus venom. Int Wound J. 2011;8(3):245-52. 